\section{BMJ Paediatrics Open}

\title{
Impact of lockdown and school closure on children in special schools: a single- centre survey
}

\author{
Tapomay Banerjee (D) , Amjad Khan, Piriyanga Kesavan
}

To cite: Banerjee T, Khan A, Kesavan P. Impact of lockdown and school closure on children in special schools: a single-centre survey. BMJ Paediatrics Open 2021;5:e000981. doi:10.1136/ bmjpo-2020-000981

- Additional material is published online only. To view, please visit the journal online (http://dx.doi.org/10.1136/ bmjpo-2020-000981).

Received 8 December 2020 Accepted 5 February 2021

\section{ABSTRACT}

Special schools play a significant role in the daily lives of children and young people with special educational needs and disabilities. We explored the impact of the COVID19-related first lockdown and resulting school closure by surveying parents whose children attended three special schools in Bedford, UK. We asked about anxiety and impact on emotional well-being and education. We received 53 responses from parents: 31 felt their child was more anxious during the lockdown period/school closure compared with beforehand and 42 felt their child's emotional well-being had been affected. Children and young people attending special schools may have struggled both academically and emotionally during the COVID-19 pandemic.

Special schools play a significant role in the daily lives of children and young people (CYP) with special educational needs and disabilities (SEND). Community paediatric services in Bedford, a town in the East of England, UK, offer clinical support to three local special schools. In this study, we explored the impact of the first (spring/summer 2020) COVID-19 lockdown and school closure on these children. CYP attending special schools in Bedford who are under the care of community paediatricians $(n=397)$ were eligible for the study. Parents of these children who were seen in virtual clinics between 1 July 2020 and 31 October 2020 were approached $(n=110)$. The link to the questionnaire (see online supplemental appendix 1) was sent to parents by telephone/email after explaining the study and obtaining verbal consent. The Research Hub within Cambridgeshire Community Services NHS Trust approved the project as a service evaluation.

All responses were recorded in the IQVIA Connection survey website (https://www. oc-meridian.com/cambsCom munitySe rvices). No sensitive or personal identifiable data were used. We received responses from 53/110 parents. Of their 53 children, 31 had autism spectrum disorder or attention deficit hyperactivity disorder or both, 14 had learning disabilities, 5 had cerebral palsy or global developmental delay and 3 had other conditions, such as chromosomal deletions. 8 children were shielding themselves, as per UK government advice. 24 of them could speak effectively, 22 could use some words but were unable to have a conversation and 7 were non-verbal.

We asked parents about the emotional wellbeing of their children and signs of increased anxiety during the lockdown period/school closure. 42/53 parents thought their child's emotional well-being had been affected to varying degrees (table 1). 31/53 parents felt their children were more anxious during the lockdown period/school closure compared with beforehand. Parental comments (table 2)
Check for updates

(c) Author(s) (or their employer(s)) 2021. Re-use permitted under CC BY-NC. No commercial re-use. See rights and permissions. Published by BMJ.

Paediatrics, Cambridgeshire Community Services NHS Trust, Bedford, Bedfordshire, UK

Correspondence to

Dr Tapomay Banerjee; tapomay. banerjee@nhs.net

\section{Table 1 Emotional well-being during school closure}

How much has your child's emotional well-being been 1. Not at all-11 affected during COVID-19

2. Somewhat -11

3. Moderately -14

4. A lot -17

5. Extreme (crisis situation) -0

What were the signs of anxiety

1. Behavioural difficulties and frustration -30

2. More agitated than usual -21

3. Sleep difficulties -13

4. Panic attacks -2

5. Others -5 
Table 2 Summary of comments and responses from parents

Difficulties during pandemic

\section{Faced difficulties}

1. My son's obsessions have taken over; his emotions have meant he hasn't been accessing any forms of learning. School provides the structure that he requires.

2. Struggled emotionally due to lack of understanding of restrictions and guidelines that are in place.

3. Missed the interaction with her peers and teachers.

4. Violent challenging behaviour and increase in meltdowns

5. Lost important academic progress as a result; severely affected emotionally.

Did not face difficulties

1. Anxiety levels were through the roof on a normal school day, during lockdown anxiety levels have dropped incredible amounts, and she is able to actually learn now.

2. Doesn't understand what's happening and why school closure

Support accessed
$\begin{aligned} & \text { 1. I didn't know they existed, so carried on as normal. } \\ & \text { 2. Had family support } \\ & \text { 3. Spoke to nursing team at school and paediatrician throughout lockdown. Also had contact with } \\ & \text { social worker. } \\ & \text { 4. Managed as best as I could at home. Did speak to his social worker from the children with } \\ & \text { disabilities team. }\end{aligned}$
$\begin{aligned} & \text { Any suggestions for } \\ & \text { improvement }\end{aligned}$
$\begin{aligned} & \text { 2. Mot really. Respite would have been great but unable to access due to shielding. } \\ & \text { 3. Being able to see his teacher and friends on zoom may have helped! } \\ & \text { 4. More information generally concerning emergency phone numbers. It would have been useful } \\ & \text { to have a list of names and numbers of professionals that we could have phoned in a crisis. We } \\ & \text { had a couple of times when it would have been nice to have had someone to talk to get advice } \\ & \text { and support. (Especially at weekends, when the nursing teams were not working.) } \\ & \text { 5. School being more flexible in their times of admitting children, so she could have gone to school } \\ & \text { and informing us of what the day would look like, I have had very little information to help her } \\ & \text { return at all or discuss how things will be different }\end{aligned}$

noted loss of structure, social interaction and academic progress with the closure of schools. However, one parent found a positive impact with reduction in anxiety during the lockdown. Parents made various useful suggestions including out of hours support, provision of respite, more communication with school (teachers and friends) and a phased and flexible school return (table 2). Eighteen parents felt that their child was affected both academically and emotionally; 16 only emotionally; 3 parents felt their child struggled only academically; and 11 were not affected at all. Five mentioned other difficulties (ie, physically unwell, restless and uncooperative, lost sleep routine and naughtier). The majority of parents were able to help their children with usual support from their paediatricians, nurses, school or family (table 2) and only one parent sought help from Child and Adolescent Mental Health Services (CAMHS).

Our findings suggest that the emotional well-being of some CYP attending special schools may have been negatively affected during the lockdown period/school closure. Researchers in China identified an increased incidence of anxiety, sleep difficulties, and suicide in the general population of China during the COVID-19 pandemic. ${ }^{1}$ A systematic review of 80 studies by Loades et $a l^{2}$ showed an increased risk of depression and anxiety during social isolation and loneliness in previously healthy children.
Special schools play a vital role in the physical, social, emotional and cognitive development of CYP with special educational needs. Closing these schools for an extended period may negatively impact the learning and emotional well-being of these CYP and may have little role in preventing the spread of COVID-19. In the current COVID-19 pandemic, studies have predicted that school closures alone would reduce mortality by only $2 \%-4 \%$, which is less than other social distancing measures. ${ }^{3}$ However, we also recognise the importance of following appropriate safety measures in special schools as a significant number of these CYP are vulnerable to infections.

Our study has significant limitations. It was conducted in a single centre, included a small number of participants, and did not use a validated questionnaire. However, we hope it will help in the understanding of challenges faced by some CYP with SEND during this pandemic.

\section{PATIENT AND PUBLIC INVOLVEMENT STATEMENT}

This survey requested parent feedback about the emotional wellbeing of children and young people attending three special schools. Patients and members of the public were not involved in designing or carrying out the survey.

Acknowledgements The authors would like thank all the wonderful children and their parents in special schools in Bedford who provided their feedbacks. Also 
they thank Claire Lucas, special needs nursing administrator who helped them to collect data. Authors would like to thank Dr Paula Waddingham, Research Manager Dr David Vickers, Medical Director, CCS and Deborah McNeill patient experience information analyst, who helped in developing our questionnaire. We are thankful to Dr Rahul Banerjee, Associate Professor, Department of Chemical Sciences, Indian Institute of Science Education and Research (IISER), Kolkata for his advice in writing this article.

Contributors TB developed the concept of the study and designed the questionnaire. AK helped in developing questionnaire and PK helped in data collection. All the authors have contributed to the final draft and approved it.

Funding The authors have not declared a specific grant for this research from any funding agency in the public, commercial or not-for-profit sectors.

Competing interests None declared.

Patient consent for publication Not required.

Provenance and peer review Not commissioned; externally peer reviewed.

Supplemental material This content has been supplied by the author(s). It has not been vetted by BMJ Publishing Group Limited (BMJ) and may not have been peer-reviewed. Any opinions or recommendations discussed are solely those of the author(s) and are not endorsed by BMJ. BMJ disclaims all liability and responsibility arising from any reliance placed on the content. Where the content includes any translated material, BMJ does not warrant the accuracy and reliability of the translations (including but not limited to local regulations, clinical guidelines, terminology, drug names and drug dosages), and is not responsible for any error and/or omissions arising from translation and adaptation or otherwise.

Open access This is an open access article distributed in accordance with the Creative Commons Attribution Non Commercial (CC BY-NC 4.0) license, which permits others to distribute, remix, adapt, build upon this work non-commercially, and license their derivative works on different terms, provided the original work is properly cited, appropriate credit is given, any changes made indicated, and the use is non-commercial. See: http://creativecommons.org/licenses/by-nc/4.0/.

ORCID iD

Tapomay Banerjee http://orcid.org/0000-0003-1482-9808

\section{REFERENCES}

1 Wang C, Pan R, Wan X, et al. Immediate psychological responses and associated factors during the initial stage of the 2019 coronavirus disease (COVID-19) epidemic among the general population in China. Int J Environ Res Public Health 2020;17:E1729.

2 Loades ME, Chatburn E, Higson-Sweeney N, et al. Rapid systematic review: the impact of social isolation and loneliness on the mental health of children and adolescents in the context of COVID-19. J Am Acad Child Adolesc Psychiatry 2020;59:1218-39.

3 Viner RM, Russell SJ, Croker $\mathrm{H}$, et al. School closure and management practices during coronavirus outbreaks including COVID-19: a rapid systematic review. Lancet Child Adolesc Health 2020;4:397-404. 